\title{
DEFORMATION AND IMPROVEMENT OF THE IR TRANSMISSION OF SINGLE-CRYSTAL SILICON BY DIRECT CURRENT HEATING
}

\author{
DEFORMACIJA IN IZBOLJŠANJE IR PRENOSA \\ MONOKRISTALNEGA SILICIJA Z ENOSMERNIM TOKOM
}

\author{
Kiyotaka Miura ${ }^{1}$, Yasuhiko Shimotsuma ${ }^{1}$, Masaaki Sakakura ${ }^{2}$, Shunsuke Gunji ${ }^{1}$, \\ Taiki Sakamoto ${ }^{1}$, Kohei Morishita ${ }^{3}$, Satoru Hachinohe ${ }^{4}$ \\ ${ }^{1}$ Kyoto University, Graduate School of Engineering, Department of Material Chemistry, Kyoto 615-8510, Japan \\ ${ }^{2}$ Kyoto University, Hitachi Zosen Collaborative Research Division, Kyoto 615-8520, Japan \\ ${ }^{3}$ Kyoto University, Graduate School of Engineering, Materials Science and Engineering, Kyoto 606-8501, Japan \\ ${ }^{4}$ Proud INC., 6-9 Fudanotsuji, 2-chome, Higashi-Omi-shi, Shiga 527-0024, Japan \\ miura2@func.mc.kyoto-u.ac.jp
}

Prejem rokopisa - received: 2016-07-14; sprejem za objavo - accepted for publication: 2016-08-02

doi: $10.17222 /$ mit. 2016.158

\begin{abstract}
We confirmed that the deformation occurred at about $800{ }^{\circ} \mathrm{C}$ when $\mathrm{CZ}-\mathrm{Si}$ was pressure and heat treated by a pulse-heatingmethod, spark plasma sintering (SPS), while at the same time, the absorption peak of silicon single crystal produced using the Czochralski process (CZ-Si), which was a major issue for infrared transparent material in the vicinity of $9 \mu \mathrm{m}$, was also confirmed to have been reduced within a short time. The absorption coefficient in the vicinity of $9 \mu \mathrm{m}$, which was derived from the interstitial oxygen, decreased the most at $800{ }^{\circ} \mathrm{C}$, and the absorption derived from the stretching mode of $\mathrm{Si}-\mathrm{O}$ observed in the vicinity of $9.7 \mu \mathrm{m}$ reached its maximum at $800^{\circ} \mathrm{C}$. This is considered to have been due to the migration of interstitial oxygen via clusters to change the material into amorphous $\mathrm{SiO}_{2}$. It was confirmed that the impact of the applied pressure direction was relative to crystal orientation on the peak of $9 \mu \mathrm{m}$. It was also found that the deformation was the maximum from the (110) plane, that the change in absorption coefficients before and after deformation was the largest, and that the relationship turned out to be (110)> (100)> (111). The dislocation lines in the sample after the deformation of the (100) plane were observed using EBSD, and the polarization dependencies of transmittance in the infrared region were measured for the planes parallel and perpendicular to the applied pressure.
\end{abstract}

Keywords: silicon, spark plasma sintering, infrared transparent material, interstitial oxygen, molding

Potrdili smo, da se je deformacija zgodila pri okoli $800{ }^{\circ} \mathrm{C}$, ko je bila CZ-Si tlačno in toplotno obdelana s pulzno toplotno metodo sintranja z iskrečo plazmo (angl. SPS), medtem ko je bil hkrati dosežen absorpcijski vrh silicijevega monokristala z uporabo Czochralskijevega postopka (CZ-Si), pri katerem je glavno težavo predstavljal infrardeči prosojni material pri približno $9 \mu \mathrm{m}$, saj je bil zmanjšan $\mathrm{v}$ zelo kratkem času. Absorpcijski koeficient pri približno $9 \mu \mathrm{m}$, ki je bil pridobljen iz intersticijskega kisika, se je najbolj znižal pri $800{ }^{\circ} \mathrm{C}$ in opazili smo absorpcijo, ki je izhajala iz raztezka Si-O, in je v bližini $9,7 \mu \mathrm{m}$ pri $800{ }^{\circ} \mathrm{C}$ dosegla svoj maksimum. Iz tega izhaja, da je bil zaradi migracije intersticijskega kisika preko skupin material spremenjen $v$ amorfni $\mathrm{SiO}_{2}$. Potrdili smo, da je bil vpliv povezan z uporabo smeri tlaka, v primerjavi s kristalno orientacijo na področju $9 \mu$ m. Ugotovljeno je bilo tudi, da je bila deformacija največja na (110) ravnini in da je sprememba koeficientov absorpcije, pred in po deformaciji, največja ter da se je pokazalo razmerje $(110)>(100)>(111)$. Opazili smo premikanje linije v vzorcu po deformaciji (100), ravnine so bile opazovane $\mathrm{z}$ uporabo EBSD ter $\mathrm{z}$ uporabo polarizacije odvisnosti od prepustnosti v infrardečem območju, ki smo jo izmerili v ravnini vzporedno in pravokotno glede na tlak.

Ključne besede: silicij, sintranje z iskrečo plazmo, infrardeči prozorni material, intersticijski kisik, modeliranje

\section{INTRODUCTION}

Pyroelectric infrared sensors, commonly used in motion sensors and similar devices, are required to efficiently detect infrared radiation with a wavelength of approximately $9 \mu \mathrm{m}$. Silicon produced using the Czochralski process (CZ Silicon), can be obtained at low prices, but can only be used for IR rays in a relatively narrow band (around 1.2-6 $\mu \mathrm{m}$ ) since the oxygen eluted from the quartz crucible is trapped in the crystal, which results in the presence of absorption near $9 \mu \mathrm{m}$ that arises from interstitial oxygen. ${ }^{1-3}$ Silicon can be produced as either a single-crystalline form by the Czochralski (CZ) crystal-growth process or the float zone (FZ) method. FZ silicon is grown without a quartz crucible and is thus almost completely oxygen-free, making the absorption of $9 \mu \mathrm{m}$ much less pronounced, but FZ silicon is expensive. If this absorption band at $9 \mu \mathrm{m}$ is improved, the wavelength range of infrared transparent windows or lenses of CZ silicon crystal may possibly be expanded. It is known that the absorption band at $9 \mu \mathrm{m}$ due to interstitial oxygen can be reduced by a long heat treatment (for several to several dozen hours) because of the conversion of $\mathrm{Si}$ into $\mathrm{SiO}_{x}(x \leq 2) .{ }^{4-6}$ In addition, silicon, which is naturally brittle owing to its covalent character, easily cracks under a small load. Thus, the conventional process used to obtain a specific lens shape is expensive. Moreover, it is difficult to shape aspherical lenses, which are ideal and highly efficient shapes for focusing. To 


\section{K. MIURA et al.: DEFORMATION AND IMPROVEMENT OF THE IR TRANSMISSION OF SINGLE-CRYSTAL SILICON ...}

solve these problems, a silicon lens fabricated by hot pressing has been investigated. ${ }^{7}$ However, in hot pressing, single-crystal silicon is pressed at $1405^{\circ} \mathrm{C}$, just below the silicon's melting temperature. Therefore, the dislocation density is large. As a result, the transmittance is reduced to $10-20 \%$. When the sample is recrystallized, the dislocation density is reduced, and the transmittance is restored to about $40 \%$. However, a heat treatment is required after hot pressing. ${ }^{7}$

We have recently succeeded in manufacturing a silicon lens at around $800{ }^{\circ} \mathrm{C}$, (roughly $600{ }^{\circ} \mathrm{C}$ lower than the temperature for hot pressing) by direct current heating using a spark plasma sintering (SPS) system. Furthermore, we confirmed that the interstitial oxygen decreased in a short time by adding pressure with direct current heating. The aims of the present study are to 1) provide a silicon material for an infrared transmitting member that secures transmittance for infrared of wavelength around $9 \mu \mathrm{m}$ and can be used for a wide range of wavelengths and 2) provide an infrared transmitting member made of the silicon material.

\section{EXPERIMENTAL PART}

Single-crystal silicon $(\Phi 6 \times 4 \mathrm{~mm})$ grown by the Czochralski process was used as the starting material. The samples have 100,110, and 111 planes perpendicular to the axis of pressing. The samples were heated to the desired temperature under a uniaxial compressive pressure in a carbon die with an inside diameter of $15 \mathrm{~mm}$ by the SPS system (LABOX-125, Spark Plasma Sintering System, Sinter Land, Japan). The SPS system is made up of a uniaxial press, punch electrodes, vacuum chamber, direct current (DC) pulse generator and position, temperature, and pressure measuring units. The temperature was increased from $700{ }^{\circ} \mathrm{C}$ to $1100{ }^{\circ} \mathrm{C}$. The heating rate was $100{ }^{\circ} \mathrm{C} / \mathrm{min}$ from room temperature to the desired temperature. The sample temperature was controlled by adjusting the pulse duration, current and voltage, and measured on the silicon surface directly by a radiation thermometer. The uniaxial pressure was changed between $0.1 \mathrm{kN}$ and $8 \mathrm{kN}$. The pressure rising rate was changed between $0.05 \mathrm{kN} / \mathrm{min}$ and $2 \mathrm{kN} / \mathrm{min}$. After the samples had been heated to the pre-set temperature under a uniaxial compressive pressure of $0.4 \mathrm{kN}$, the pressure was increased to the pre-set pressure while keeping the temperature the same. In the heat/press deformation of the plasma sintering system (SPS) in this study, when the temperature of silicon reached about $400{ }^{\circ} \mathrm{C}$, there was a change in electrical resistance, which confirmed the start of direct power supply to the interior of silicon. After being cut into 1-mm-thick chunks, the specimens were mirror polished and then used for infrared transmission measurements.

Infrared transmission was measured in the range of $2-12 \mu \mathrm{m}$ at room temperature by FT-IR to determine the absorption coefficient. In addition, to compare the differences between a plane perpendicular and a plane parallel to the axis of the pressure, the polarization dependence of the infrared transmission spectrum was investigated using a holographic wire grid polarizer. The crystal orientation and the distribution of dislocations for the $\mathrm{CZ}$ silicon crystal after transformation were also characterized by electron backscatter diffraction (EBSD).

\section{RESULTS AND DISCUSSION}

Figure 1 shows a photograph and the IR absorption spectra of the $\mathrm{CZ}$ silicon that was compressed by changing the temperature at a pressure of $4 \mathrm{kN}$ perpendicular to a plane of silicon (100). The absorption coefficient around $9 \mu \mathrm{m}$, derived from the interstitial oxygen decreases to its minimum at $800{ }^{\circ} \mathrm{C}$, and then increased as the temperature rose from $900{ }^{\circ} \mathrm{C}$ to 1100 ${ }^{\circ} \mathrm{C}$. In contrast, the absorption derived from the $\mathrm{Si}-\mathrm{O}$ stretching mode observed around $9.7 \mu \mathrm{m}$ was at its maximum at $800{ }^{\circ} \mathrm{C}$. This is because the interstitial oxygen had moved and changed to amorphous Silica $\mathrm{SiO}_{2}$ over the cluster $\left(\mathrm{SiO}_{4}\right)$. It is well known that interstitial oxygen is transformed into oxygen precipitation and into amorphous $\mathrm{SiO}_{2}$ by heat treatment over a long
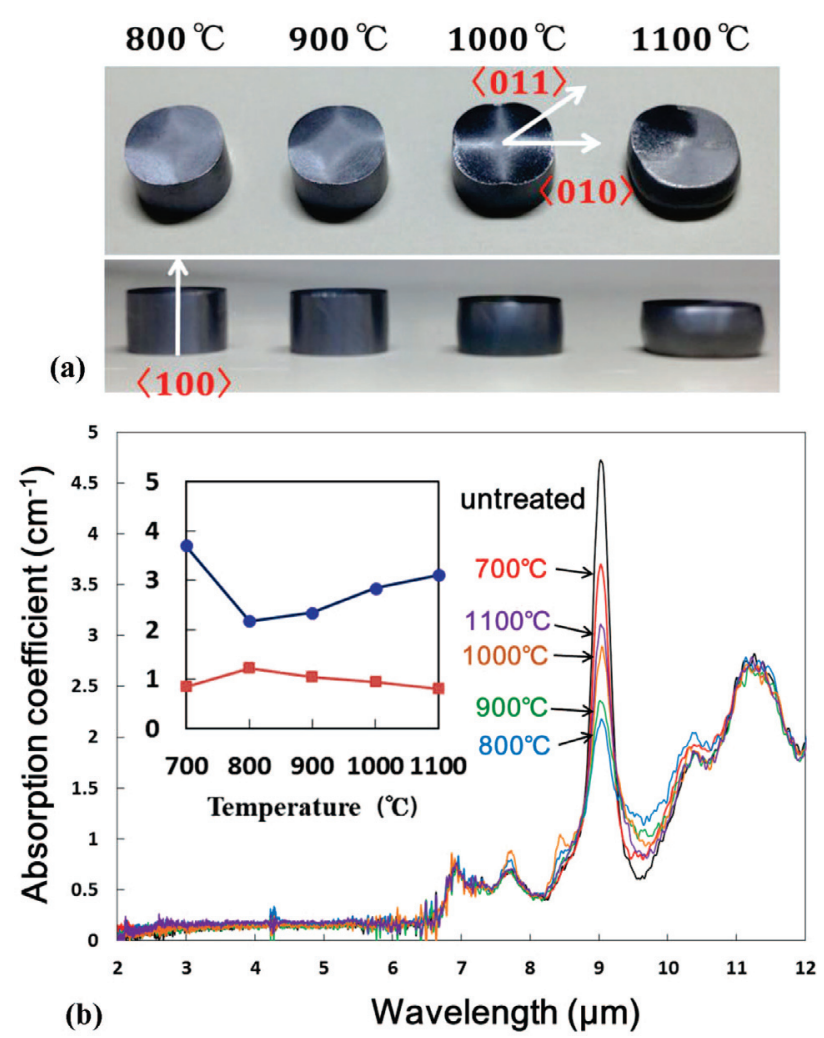

Figure 1: a) Image and b) IR absorption spectra of $\mathrm{CZ}$ silicon obtained by changing the temperature reached by applying a pressure $(4 \mathrm{kN})$ perpendicular to a plane of silicon (100)

Slika 1: a) Slika in b) IR spektri absorpcije CZ silikona, pridobljenega $\mathrm{s}$ spreminjanjem temperature, dosežene $\mathrm{z}$ dodajanjem tlaka $(4 \mathrm{kN})$ pravokotno na površino silikona (100) 
K. MIURA et al.: DEFORMATION AND IMPROVEMENT OF THE IR TRANSMISSION OF SINGLE-CRYSTAL SILICON ...

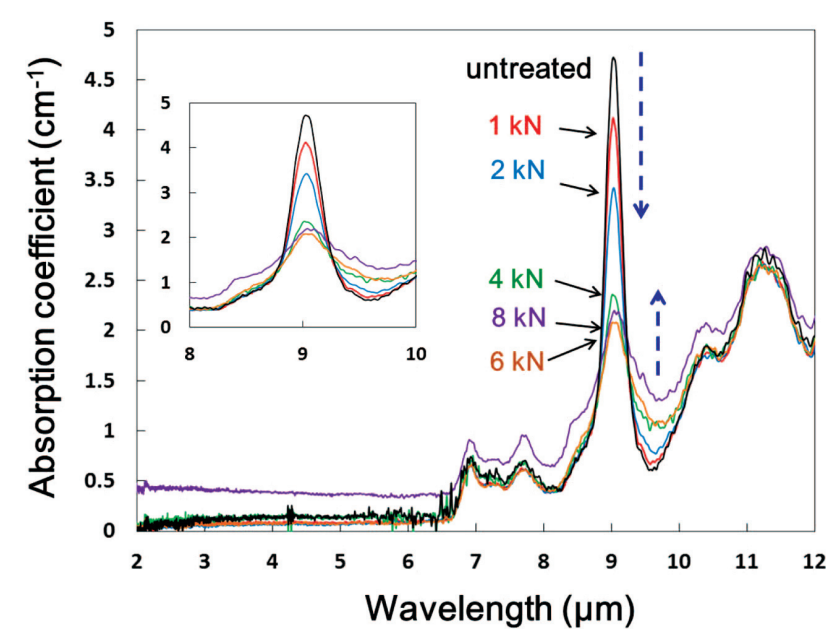

Figure 2: IR absorption spectra of $\mathrm{CZ}$ silicon obtained by changing the ultimate pressure at $900{ }^{\circ} \mathrm{C}$

Slika 2: IR absorpcija spektrov CZ silikona, pridobljenega s spreminjanjem končnega tlaka pri $900{ }^{\circ} \mathrm{C}$

time. ${ }^{8,9}$ The reason for the maximum reduction of interstitial oxygen at $800{ }^{\circ} \mathrm{C}$ is controlled oxygen diffusion. ${ }^{10,11}$ We also found that in the high-temperature region beyond $800{ }^{\circ} \mathrm{C}$, the super-saturation of the $\mathrm{SiO}_{2}$ that formed was reduced and the process of crystal growth from nucleation did not progress further. In addition, $\mathrm{SiO}_{2}$ that had segregated once in the low-temperature region, decomposed again. Therefore, the optimum temperature of the decreasing absorption band at $9 \mu \mathrm{m}$ is estimated to be $800{ }^{\circ} \mathrm{C}$.

Similarly, when the ultimate pressure is changed, the $9 \mu \mathrm{m}$ absorption decreased proportionately with the pressure, and it was confirmed that the pressure at the time of deformation, greatly contributes to the movement of interstitial oxygen. Figure 2 shows the IR spectrum of the samples pressed at $1,2,4,6$, and $8 \mathrm{kN}$ by fixing the temperature at $900{ }^{\circ} \mathrm{C}$. The absorption band at $9 \mu \mathrm{m}$ decreases in proportion to increasing loads, except for the 8 $\mathrm{kN}$ load. This result indicates that the precipitation of $\mathrm{SiO}_{2}$ clusters or particles is increased by dislocations due to high pressure. In contrast, the absorption band at $9 \mu \mathrm{m}$

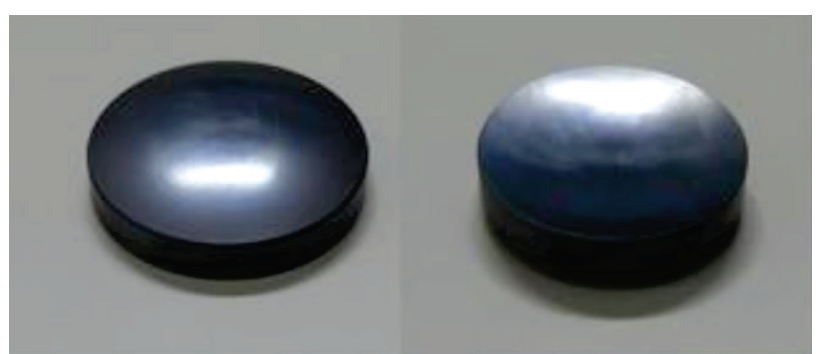

Figure 3: A silicon single-crystal lens obtained from a CZ silicon disk $(\Phi 22 \times 4 \mathrm{~mm})$ by molding at around $800{ }^{\circ} \mathrm{C}$ (actual sample temperature), which is about $600{ }^{\circ} \mathrm{C}$ lower than the melting temperature, by using an SPS system

Slika 3: Silikonski monokristalni leči, pridobljeni iz CZ silikonskega diska $(\Phi 22 \times 4 \mathrm{~mm}) \mathrm{z}$ dolivanjem na okoli $800{ }^{\circ} \mathrm{C}$ (dejanska temperatura vzorca), ki je za $600{ }^{\circ} \mathrm{C}$ nižja kot talilna temperatura, pri uporabi SPS-sistema
(100)
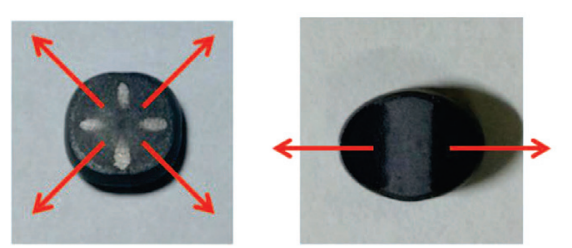

(111)

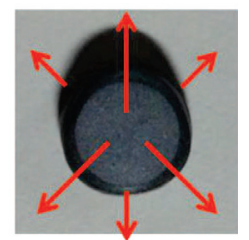

Figure 4: Shape difference of samples obtained by pressure perpendicular to the pressing axis on 100,110 , and 111 planes at $1000{ }^{\circ} \mathrm{C}$ and $4 \mathrm{kN}$

Slika 4: Različne oblike vzorcev, pridobljene s tlakom pravokotno s potisno osjo na 100,110 in 111 pri $1000{ }^{\circ} \mathrm{C}$ in $4 \mathrm{kN}$

of the sample that is pressed at $8 \mathrm{kN}$ tends to increase. The crack of the surface of this sample is observed using an optical microscope. This result indicates that the crack generates the light scattering.

From these results, it is clear that deformation due to pressure is used with heat treatment for the diffusion of interstitial oxygen. Thus, the pressing in optimum conditions can be expected to be applied for an infrared transmission lens because not only are the samples molded but also the absorption property at $9 \mu \mathrm{m}$ is improved. An example succeeded in manufacturing a silicon single crystal lens at around $800{ }^{\circ} \mathrm{C}$ (actual sample temperature) is shown Figure 3, which is about $600{ }^{\circ} \mathrm{C}$ lower than the molding temperature for the hot-pressing method, ${ }^{6}$ by using an SPS system.

In order to determine the impact of the applied pressure direction relative to crystal orientation on the peak of $9 \mu \mathrm{m}$, each sample was prepared and placed so that the crystalline planes were perpendicular to the pressing axis on the 100, 110 and 111 planes. Figure 4 and Table $\mathbf{1}$ show the obtained results. It was found that the deformation was a maximum from the (110) plane, that the change in absorption coefficients before and after deformation was the largest, and that the relationship turned out to be (110)> (100)> (111). During the deformation of the (110) plane, the transformation was parallel to the axis of the applied pressure, while, in the case of the deformation of the (100) plane, due to mutual intersection of slip planes, the interaction due to slip planes became larger and the change was smaller when compared to the (110) plane. In the (111) plane, the change was small because the slip plane is perpendicular to the loading axis.

Table 1: Absorption coefficient difference at $9 \mu \mathrm{m}$ and deformation amount of height for samples in Figure 4

Tabela 1: Koeficient absorpcije - razlika pri $9 \mu \mathrm{m}$ in deformacijska količina višine za vzorce na Sliki 4

\begin{tabular}{|c|c|c|}
\hline Crystal plane & $\begin{array}{c}\text { Absorption } \\
\text { coefficient } \\
\text { difference at } 9.0 \mu \mathrm{m} \\
\left(\mathrm{cm}^{-1}\right)\end{array}$ & $\begin{array}{c}\text { Deformation } \\
\text { amount } \\
(\mathrm{mm})\end{array}$ \\
\hline$(100)$ & 2.37 & 0.28 \\
\hline$(110)$ & 2.68 & 0.44 \\
\hline$(111)$ & 1.55 & 0.12 \\
\hline
\end{tabular}



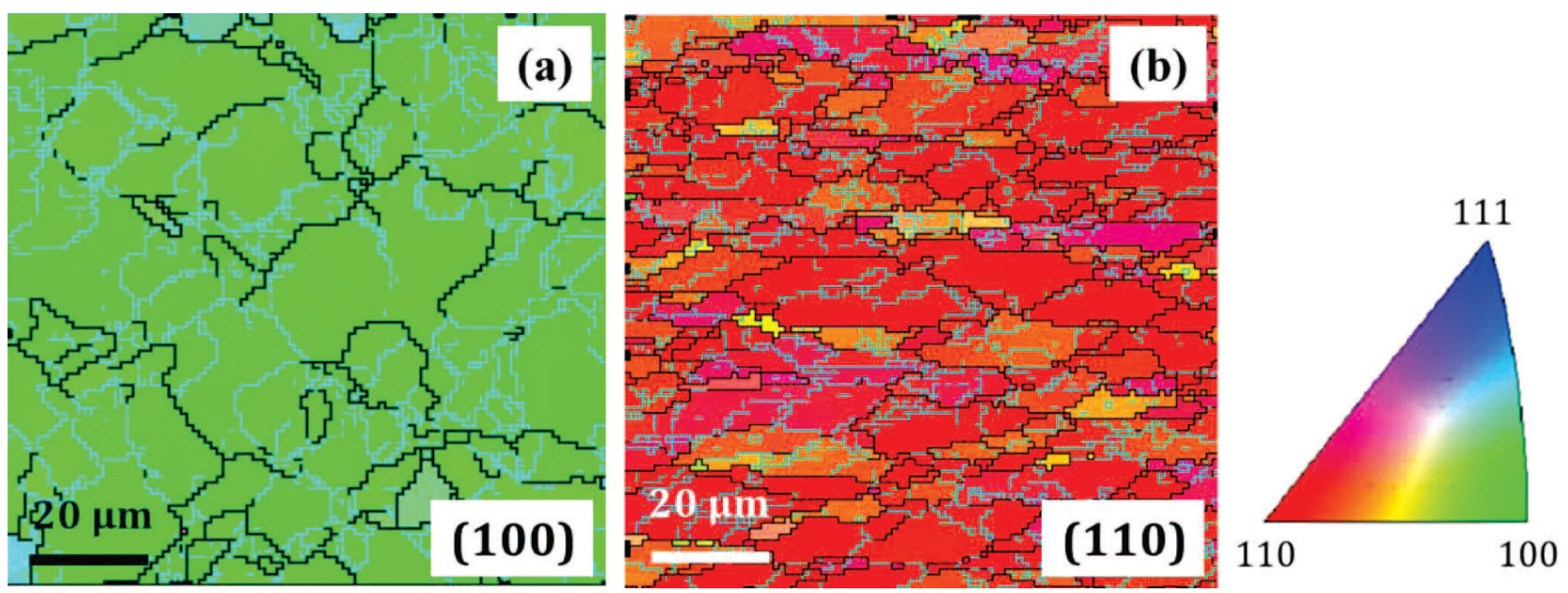

Figure 5: Dislocation lines in samples after the deformation of (100) plane observed using electron backscatter diffraction (EBSD): a) perpendicular and $b$ ) parallel to the applied pressure

Slika 5: Dislokacijske linije v vzorcih po deformaciji (100), izmerjene z uporabo EBSD: a) pravokotno in b) paralelno glede na uporabljeni tlak

The dislocation lines in the sample after the deformation of the (100) plane were observed using EBSD and the results are shown in Figure 5a and $\mathbf{5 b}$.

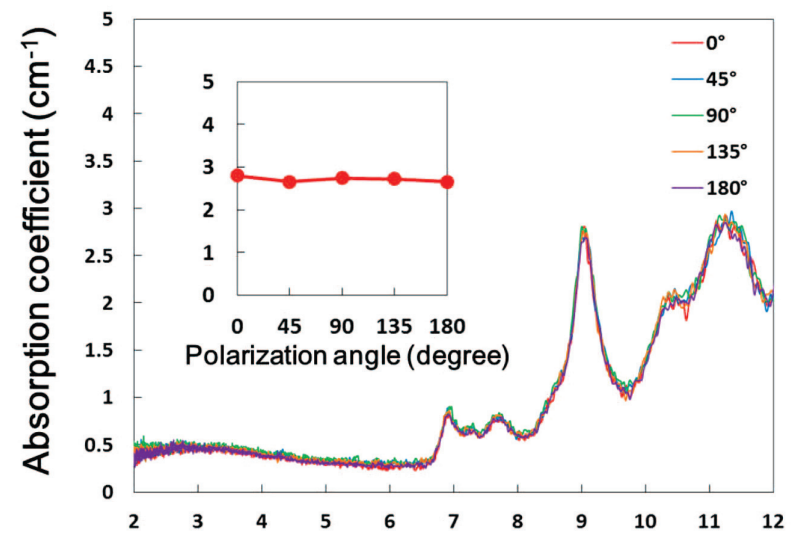

(a)

Wavelength $(\mu \mathrm{m})$

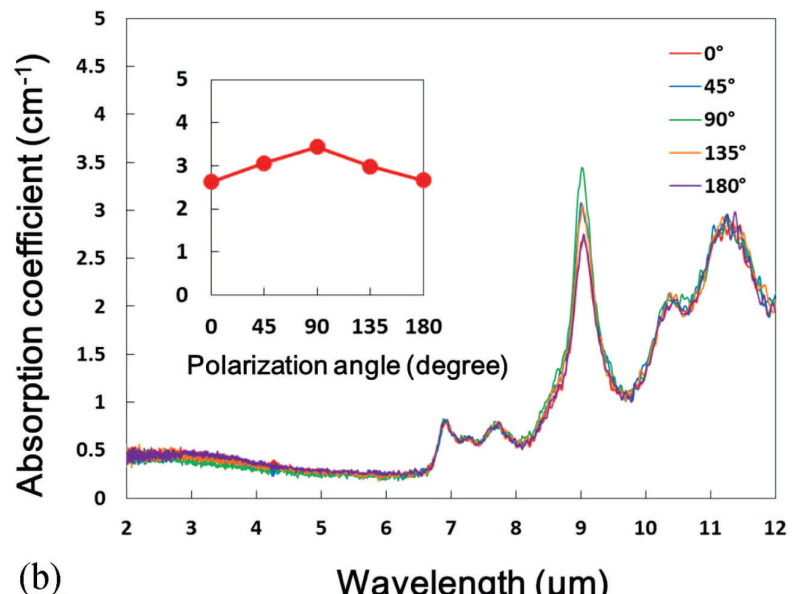

Figure 6: Polarization dependence of absorption in the infrared region obtained for samples in Figures 5a and $\mathbf{5 b}$

Slika 6: Polarizacijska odvisnost na infrardečem področju, pridobljena za vzorce iz Slike $\mathbf{5 a}$ in $\mathbf{5 b}$
As seen in Figure 5a, where the plane is perpendicular to the applied pressure, the dislocation lines enter randomly, while in Figure $\mathbf{5 b}$, where the plane is parallel to the applied pressure, the dislocations lines are oriented horizontally. Then, the polarization dependencies of absorption in the infrared region were measured for each case. The changes in IR absorption spectra are shown in Figure 6a and $\mathbf{6 b}$. In the sample in Figure 5a, no polarization dependency was observed, while in the sample of Figure 5b, where the transition lines are horizontally oriented, polarization dependency was observed in the absorption of $9 \mu \mathrm{m}$. Interstitial oxygen is known to move through the central position of $\mathrm{Si}-\mathrm{Si}$ bond along the (110) planes $^{12}$ and as a result, we can say that the interstitial oxygen segregated along the loading axis towards the dislocation lines. It can be predicted that in the pressure temperature region $\left(700-1100{ }^{\circ} \mathrm{C}\right)$, the carrier density must have increased due to the flow of direct current in the silicon, and due to the weakening of covalent bonds, a metal-like deformation with weak orientation was formed. This indicates that the dislocation lines in Figure $\mathbf{5 a}$ and $\mathbf{5 b}$ do not originate from the crystal structure and that the impact of the axis of the applied pressure is reflected in a much larger way.

\section{CONCLUSION}

We have shown that deformation occurred at $800{ }^{\circ} \mathrm{C}$ and $6 \mathrm{kN}$ when $\mathrm{CZ}-\mathrm{Si}$ was pressure and heat treated by direct current heating using the SPS system, while at the same time, the absorption peak of CZ-Si, which had been a major issue for the infrared transparent material in the vicinity of $9 \mu \mathrm{m}$, was also confirmed to have been reduced within a short time. It was also found that the deformation was the maximum from the (110) plane, that the change in absorption coefficients before and after molding was the largest, and that the relationship turned 


\section{MATERIALI IN TEHNOLOGIJE/MATERIALS AND TECHNOLOGY (1967-2017) - 50 LET/50 YEARS}

\section{K. MIURA et al.: DEFORMATION AND IMPROVEMENT OF THE IR TRANSMISSION OF SINGLE-CRYSTAL SILICON ...}

out to be $(110)>(100)>(111)$. Furthermore, we have shown that a silicon lens could be molded at around $800{ }^{\circ} \mathrm{C}$, which is about $600{ }^{\circ} \mathrm{C}$ lower than the melting temperature, by using an SPS system. Although further studies are required for elucidating the detailed mechanism behind low-temperature deformation, we can expect that single-crystal silicon formation can be realized at low temperatures of $800-900{ }^{\circ} \mathrm{C}$ and that this technique where the interstitial oxygen absorption is reduced in a short period of time at the same time as formation, can be applied in the making of infrared transmission windows and lenses.

\section{REFERENCES}

${ }^{1}$ F. A. Johnson, Lattice absorption bands in silicon, Proc. of Phys Soc., 73 (1959), 265-272, doi:org/10.1088/0370-1328/73/2/315

${ }^{2}$ S. Sadamitsu, S. Umeno, Y. Koike, M. Hourai, S. Sumita, T. Shigematsu, Dependence of the grown-in defect distribution on growth rates in czochralski silicon, Jpn. J. Appl. Phys., 32 (1993), 3675-3681, doi:org/10.1143/JJAP.32.3675

${ }^{3}$ K. Krishnan, In defects in silicon, Material Research Society Symposium Proc., 83-9 (1983), 285-292

${ }^{4}$ P. Gaworzewski, E. Hild, F. G. Kirscht, L. Vecsernyés, Infrared spedtroscopical and TEM investigations of oxygen precipitation in silicon crhystals with medium and high oxygen concentrations, Phys. Stat. Sol. (a), 85 (1984), 133-147, doi:10.1002/pssa.2210850116
${ }^{5}$ K. Tempelhoff, F. Spiegelberg, R. Gleichmann, D. Wruck, Precipitation of oxygen in dislocation-free silicon, Phys. Stat. Sol. (a), 56 (1979), 213-223, doi:10.1002/pssa.2210560123

${ }^{6}$ W. A. Tiller, S. Hahn, F. A. Ponce, Thermodynamic and kinetic considerations on the equilibrium shape for thermally induced microdefects in czochralski silicon, J. Appl. Phys., 59 (1986), 3255, doi: $10.1063 / 1.336908$

${ }^{7}$ K. Morishita, K. Nakajima, T. Fujii, M. Shiinoki, Near-net shaping of single-crystal silicon for optical lens by one-shot pressing at temperature just below silicon melting point and its demonstration of optical properties, Appl. Phys. Express, 4 (2011), 106501, doi:10.1143/APEX.4.106501

${ }^{8}$ V. E. Gusakov, General model of diffusion of interstitial oxygen in silicon and germanium crystals, Solid State Phenomena, 108-109 (2005), 413-418, doi:10.4028/www.scientific.net/SSP.108-109.413

${ }^{9}$ I. Yonenaga, K. Sumino, Influence of oxygen precipitation along dislocation on the strength of silicon crystals, J. Appl. Phys., 80 (1996) 2, 734-738, doi:10.1063/1.362881

${ }^{10}$ K. H. Yang, H. F. Kappert, G. H. Schwuttke, Minority carrier lifetime in annealed silicon crystals containing oxygen, Phys. Stat. Sol. (a), 50 (1978), 221-235, doi:10.1002/pssa.2210500126

${ }^{11} \mathrm{~K}$. Wada, N. Inoue, Growth kinetics of oxide precipitates in czochralski silicon, J. Cryst. Growth, 71 (1985), 111-117, doi:10.1016/ 0022-0248(85)90050-8

${ }^{12}$ I. Yonenaga, K. Nakajima, Dislocation dynamics in bending deformation of Si, Key. Eng. Mater., 508 (2012), 357-360, doi:10.4028/www.scientific.net/KEM.508.357 